\title{
AWARDS
}

\section{Ana Crespo}

Ana M. Crespo de Las Casas, who was honoured with the Acharius Medal of the International Association for Lichenology (IAL) at their congress in Bangkok in January, was received as a full member into the prestigious Real Academia de Ciencas Exactas, Fisicas y Naturales of Spain at a ceremony in the Academy's rooms on 28 November 2012. This was a most formal occasion at which she had to read the full text of a specially prepared dissertation. This was a wide-ranging work entitled "El discurrir de una Ciencia amable y la vigencis de sus objectivos: de Linneo al código de barras de AND se pasa por Darwin", published in book-form and distributed to those present. Ana is currently head of the Departamento de Biología Vegetal II in the Facultad de Farmacia of the
Universidad Complutense de Madrid, and renowned in particular for her pioneering work on the molecular phylogenetics and systematics of the parmelioid lichens initiated in 1995-96 when she was a visiting scientist at the former International Mycological Institute in Egham (UK). The Academy was established in 1847 by royal decree, and Ana appears to be the first in the field of wholeorganism mycology ever to be admitted, as well as one of the few women. Many of her family, friends, former and current graduate students, and also academic colleagues

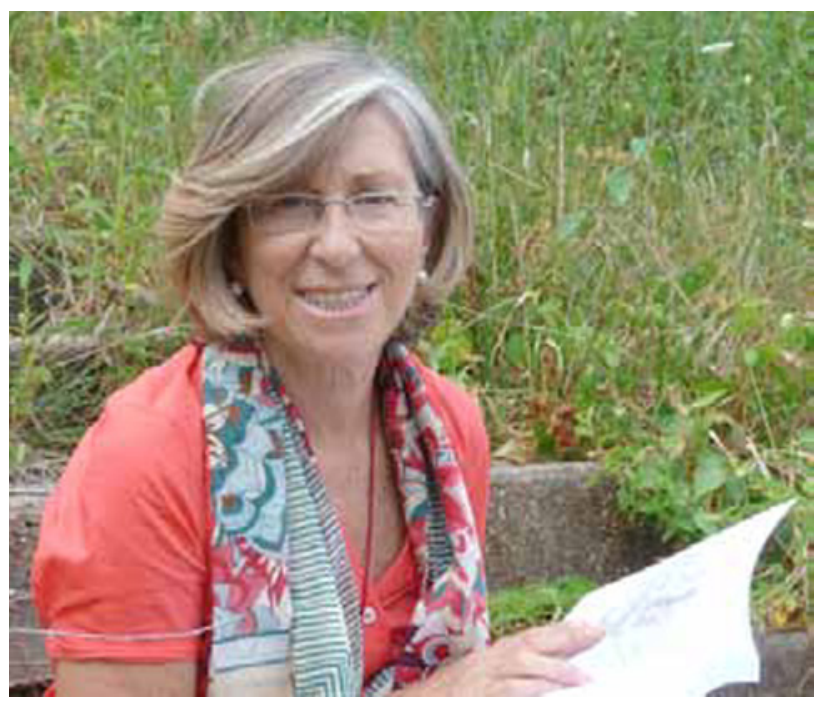

attended the two-hour ceremony, and IMA Fungus also adds its congratulations to Ana on this well-deserved further recognition of her achievements.

\section{Emil M. Mrak International Award}

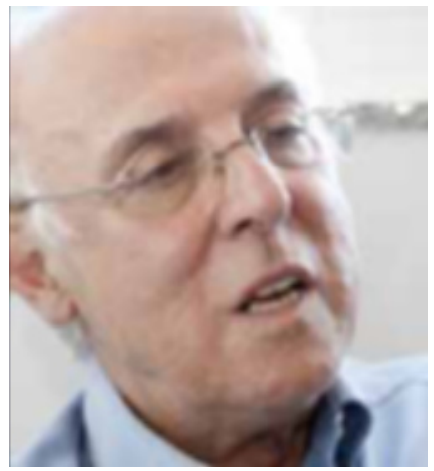

José Carmine Dianese, Emeritus Professor in the University of Brasilia and a member of the IMA Executive Committee, is to receive the 2013 Emil M. Mrak International Award. The award honours a graduate of the University of California at Davis "who is distinguished in his or her career or in service outside the United States." José was the first Brazilian to gain a $\mathrm{PhD}$ in plant pathology at Davis in 1970. For more than 40 years he has been training mycologists and plant pathologists in Brazil, 15 of whom went on to become university professors themselves, as well as painstakingly documenting the hitherto unexplored microfungal biota of the cerrado. The Award was established in 1988, and he appears to be the first systematic mycologist to have been so honoured. The IMA wishes to add its congratulations to those he will already have received.

\section{IN MEMORIAM}

\section{Gouri Rani Ghosh (1924-2012)}

Gouri Rani Ghosh died in Pondichery, Tamil Nadu, on 8 January 2012 at the age of 88 . She was born on 6 June 1924 in Orissa, and was the first female graduate of the Department of Botany at Ravenshaw College in Orissa. By the late 1940s she was writing student science text books in the Oriya language. She secured a Fulbright Fellowship in 1952 and completed a PhD in mycology at the University of Illinois in 1954. Back in Orissa, she started to work on myxomycetes, and also on Gymnoascaceae in collaboration with Harold H. Kuehn and G. F. Orr, on which she became a leading authority. Her research on these fungi continued into the 1980s, securing grants, and training four $\mathrm{PhD}$ students of her own; there were also further collaborations with mycologists overseas, notably Allan Piers in the USDA. Her investigations were both ontogenetic and systematic. Amongst the new fungi in the family she named, are the genera Gymnoascoideus and Orromyces which remain in use today, and species of

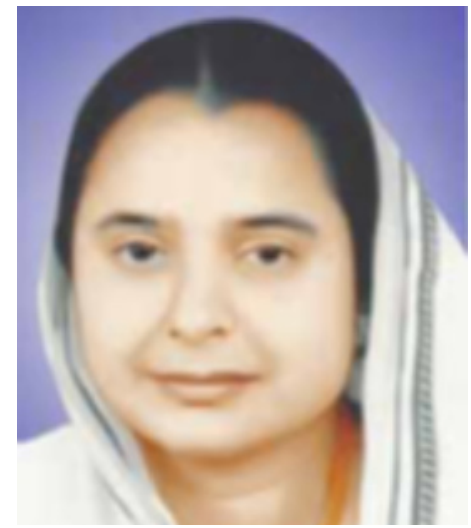


various genera in the family. She was also one of the founder members of the Indian Mycological Society.
Kirity Roy kindly provided notes on Gouri's life and achievements, as well a the portrait included here.

\section{Carl Lennart Holm (1921-2012)}

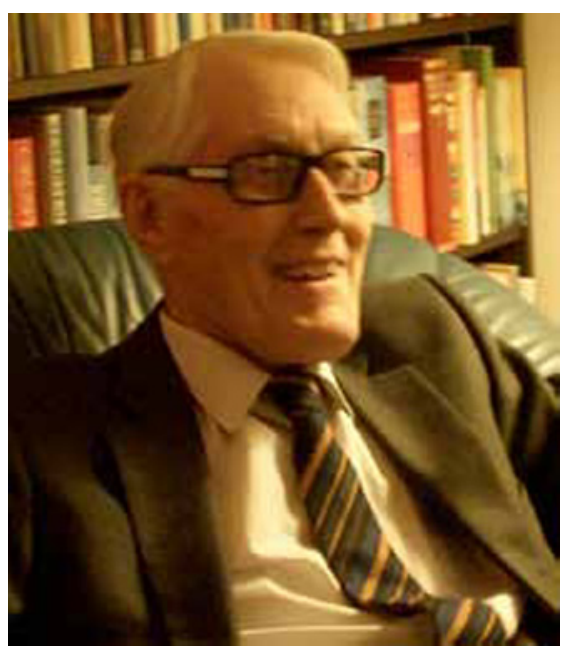

Lennart Holm, a leading authority on pyrenomycete taxonomy for over sixty years, and a nomenclatural sage, passed away in Uppsala on 28 July 2012. Born in
Umeå on 29 April 1921, he was aged 91. Lennart was nevertheless busy working almost to the end on a fascicle of Fungi Exsiccati Suecici, bringing the total number of specimens distributed in the series to a staggering 3800 . The exsiccate had been initiated in 1934 by Lennart's mentor, Johan A. F. Nannfeldt (1904-1985), and Lennart assumed that mantle from Nannfeldt. Lennart's most influential work was perhaps his $\mathrm{PhD}$ on Pleosporaceae (1957), which laid the foundations of a new taxonomy for the family, including revised generic concepts and clarifications of the application of many species names through careful typifications. He went on to publish revisions of various genera, especially of pyrenomycetes in the Nordic countries, and also developed interests in rusts. In addition he started to reveal the

\section{Dorothy Jean Stamps (1927-2012)}

Jean Stamps, as she was always known, was born in West Bromwich on 10 February 1927, and died in London on 3 October 2012 aged 85 years. She graduated in plant biology from the University of Birmingham in 1948, continuing there to complete a $\mathrm{PhD}$ on variability in Phytophthora cactorum in 1951. Jean was immediately recruited by the then Commonwealth Mycological Institute in Kew as subeditor of the Review of Applied Mycology. However, under the tutelage of Grace M. Waterhouse (1906-1996) she became increasingly involved in the identification of Phytophthora and Pythium species, becoming a world authority on Phytophthora. She was always pleased to put her immense knowledge at the disposal of others, distilling that on Phytophthora into the renowned "tabular keys"; first with F J Newhook and Grace (Mycological Papers 143, 1978), and then with a new edition in 1990 (Mycological Papers $162,1990)$ in which she was assisted by
Geoffrey S. Hall. Those keys, which placed the species into six categories, remain a standard work and continue to be regularly cited. In addition she prepared numerous authoritative accounts of selected species for the Institute's Descriptions of Pathogenic Fungi and Bacteria. Jean was modest and unassuming, but on courses and at conferences she would amaze with her expertise. From 1967 until her retirement in 1987, Jean had the responsibility for what became the Review of Plant Pathology, overseeing its migration onto a computerized production system and also to $\mathrm{CAB}$ International headquarters in Wallingford, Oxfordshire. Jean, an accomplished musician, also served as Librarian of the British Mycological Society for many years, receiving the Society's Benefactors' Medal in 1986. She also has the distinction of serving under six of the seven Directors the Institute had since its establishment in 1920 until it ceased in 1998. previously hardly recognized diversity of microfungi associated with particular Scandinavian plants, such as those on Dryas, Equisetum, Juniperus, Rubus chamaemorus, and ferns - often in conjunction with his wife Kerstin. Lennart devoted much time to clarifying the nomenclatural status of generic names, and served for many years on the Nomenclature Committee for Fungi established by successive International Botanical Congresses, including the role of Chair. He was also responsible for the recommendation to use the colon (:) notation to indicate the sanctioned status of names in author citations introduced at the Sydney Congress in 1981. Lennart was always generous with his time, and with Kerstin always enjoyed attending field meetings, and also entertaining mycologists at their home near Uppsala.

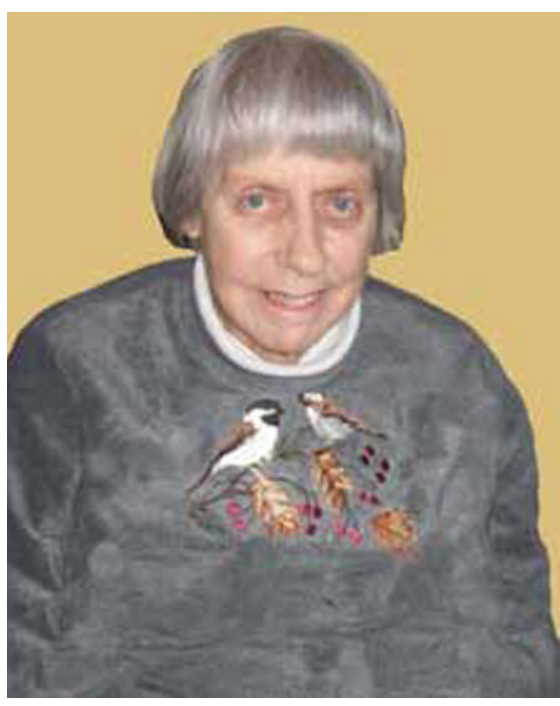

The portrait presented here was kindly supplied by Gerald Crowther. 